\title{
Analýza zátěžových testů u skialpinistů
}

\section{Stress test analysis of ski mountaineers}

\section{Matouš Jindra, Ladislav Vomáčko, Dita Formánková, Klára Coufalová}

\author{
Fakulta tělesné výchovy a sportu Univerzity Karlovy, Praha
}

\begin{abstract}
Abstrakt:
$\mathrm{Na}$ základě nedostatku odborných informací o soutěžním skialpinismu uvádíme analýzu 3 typi̊ zátěžových testư u skialpinistů. Ziskaná data byla porovnána z maximálních zátěžových testů na pásovém ergometru, bicyklovém ergometru a pásovém ergometru s využitím skialpinistických kolečkových lyží. Naměřené hodnoty prokázaly velkou technickou náročnost testu na kolečkových lyžích. Na základě těchto informací doporučujeme dlouhodobějši trénink na pásovém ergometru se skialpinistickými kolečkovými lyžemi, před zahájením maximálního zátěžového testu. Výsledky ukázaly nejmenší odchylku maximálních hodnot u respondentů, kteří měli s jízdou na skialpinistickém trenažéru předchozí zkušenosti.
\end{abstract}

\begin{abstract}
:
We analyze 3 types of maximum stress tests on the basis of the lack of professional information about competitive ski mountaineering. The obtained data was compared with the maximum stress test on the treadmill; bicycle ergometer and treadmill using a roller ski modified for ski mountaineering. The values which were measured shows great technical demands on the test using roller skis. Based on this information, we recommend long-term training on the treadmill using roller skis, before the maximum load test. The results show the smallest deviation of the maximum values among respondents who had previous experience with modified roller skis for ski mountaineering.
\end{abstract}

Klíčová slova: $\quad$ skialpinismus, maximální zátěžový test, ergometr, analýza

Key words: $\quad$ ski mountaineering, maximum stress test, ergometer, analysis

Výzkum byl podpořen z prostředků výzkumného záměru MSM0021620864 a specifického vysokoškolského výzkumu 2011-263601.

\section{Úvod}

Skialpinismus je sport, který zahrnuje prvky sjezdového a běžeckého lyžování, a zároveň specifický druh lokomoce, jenž umožňuje vybavení charakteristické pro skialpinismus.

Jedná se o kombinaci pohybu podobnému chůzi s tím rozdílem, že přenášená noha není zcela vznesena vzhůru jako při chůzi, ale je sunuta směrem vpřed. Při stoupání do kopce se nejvíce podobá běhu na lyžích klasickou technikou a některé studie je s ním i porovnávají (např. Canclini et al. 2009). Při sjezdu z kopce je pohyb naprosto stejný jako při sjezdovém lyžování. Stoupání do prudkého kopce při skialpinismu je pohyb specifický právě pro tento sport. Skialpinistické lyže umožňují stoupat do svahů i nad $25 \%$. Lyže při stoupání mají díky stoupacím pásům větší odpor a není možné provést skluz jako na lyžích běžeckých.

Navzdory masivnímu rozšiřrení skialpinismu v posledních letech zůstává výzkum na poměrně nízké úrovni. Pouze několik málo výzkumných ústavů se zabývá skialpinismem v míře rozšiřující odborné znalosti. Tosi et al. (2009) zkoumal energetickou náročnost skialpinismu a prokázal, že je pro chůzi na lyžích potřeba více energie než na chůzi nebo chůzi na sněžnicích. Voutselas et al. (2005) zjistil, že hodnota $\mathrm{VO}_{2}$ max silně koreluje s rychlostí skialpinistické chůze. Sideris et al. (2010) poukazuje na vysokou korelaci mezi rychlostí lyžařské chůze a délkou kroku.

Z dostupných zdrojů víme, že zatím nebyla provedena analýza zátěžových testů u skialpinistů. Způsobů zjištování maximálních hodnot při zátěžových testech je několik. Většina laboratoři je vybavena pásový- 
mi a cyklickými ergometry, kde je poměrně snadné změření stavu trénovanosti organismu. V současné době existují ergometry nebo trenažéry, na kterých je možné provádět pohyb i pro tak specifické sporty jako je běžecké lyžování technikou skate, a to i za použití holí, nebo jízdu s hokejovými bruslemi na speciálně uzpůsobeném pásu. Tyto nové technologie umožňují provedení zátěžových testů za téměř přirozených podmínek lokomoce daného sportu.

Rozborem maximálních zátěžových testů na různých typech ergometrů byly zjištěny rozdílné hodnoty. Canals et al. (2003) uvádí, že maximální zátěžové testy vyžadující práci více svalových skupin mají hodnoty $\mathrm{VO}_{2} \max$ vyšší. Na přístrojích stimulujících běh na lyžích jsou naměřené hodnoty jednotlivce vyšší než na běhacím páse, a na běhacím páse jsou hodnoty vyšší než na bicyklovém ergometru. Nespornou nevýhodou bicyklového ergometru je lokální únava a předčasné bolesti dolních končetin.

Rozdíl v hodnotách $\mathrm{VO}_{2}$ max mezi běžeckým pásem a bicyklovým ergometrem je zpravidla 5-10\% (Vilikus et al. 2004). Někteří autoři (Máček a Vávra, 1988) upřednostňují testy na bicyklovém ergometru kvưli dobrým podmínkám pro sledování potřebných fyziologických veličin při poměrně malých pohybech hlavy, trupu i horních končetin.

Naše studie byla zaměřena na porovnání maximálních zátěžových testů při třech rozdílných typech lokomoce. Primárně jsme byli zaměřeni na porovnání specifického zátěžového testu na širokém pásovém ergometru, který umožňuje jízdu na kolečkových lyžích s klasickými typy protokolů na bicyklovém a pásovém ergometru.

\section{Metody}

Měření se účastnilo 10 aktivních soutěžních skialpinistů ve věku $25,8 \pm 5$ let, $\mathrm{z}$ nichž někteří patří do české skialpinistické reprezentace. Maximální zátěžový skialpinistický test byl proveden na pásovém ergometru typu SATURN od firmy HP Cosmos, který svou šiŕkou umožňuje chůzi na speciálně upravených kolečkových lyžích pro klasickou techniku běžeckého lyžování. Lyže byly osazeny jednoduchým skialpinistickým vázáním, které umožňuje použití bot pro skialpinismus. Na hroty holí byly připevněny gumové koncovky, které zamezují poškození běhacího pásu. Test byl zahájen změřením klidových hodnot, následovala rozcvička trvající 4 minuty při rychlosti $3,5 \mathrm{~km} \cdot \mathrm{h}^{-1}$ a sklonu svahu $16 \%$. Po krátké pauze a dosažení setrvalého stavu srdeční frekvence pod 100 tepů/min byl zahájen test maximální zátěže. Počáteční rychlost byla stanovena na $3,5 \mathrm{~km} \cdot \mathrm{h}^{-1}$ při sklonu $20 \%$. Sklon zůstal po celou dobu na stejné úrovni a rychlost byla stupňována o $0,5 \mathrm{~km} \cdot \mathrm{h}^{-1} \mathrm{každých} 60$ sekund až do rychlosti, kterou byl respondent schopen zvládnout.

Dosažené hodnoty byly porovnány $s$ výsledky běžeckého maximálního zátěžového testu a bicyklového maximálního testu. Běžecký zátěžový test byl proveden na stejném typu pásového ergometru s jiným zátěžovým protokolem. Rozcvičení probíhalo př̀i nulovém sklonu a počáteční rychlosti $11 \mathrm{~km} \cdot \mathrm{h}^{-1}$, po třech minutách zátěže byla rychlost lineárně navýšena na $13 \mathrm{~km} \cdot \mathrm{h}^{-1}$. Celková doba rozcvičení byla 6 minut, v nichž byly ve dvou časových úsecích měřeny respirační hodnoty. Vlastní test začínal podle výkonnosti respondenta na rychlosti volené tak, aby byl schopen stupňovanou zátěž zvládnout po dobu nejméně 3,5 min. Sklon běhacího pásu při maximálním testu byl stabilně $5 \%$.

Protokol na bicyklovém ergometru začínal 6minutovým rozcvičením se zátěží $1,5 \mathrm{~W} \cdot \mathrm{kg}^{-1}$, která se v polovině rozcvičení zvedla na $2,5 \mathrm{~W} \cdot \mathrm{kg}^{-1}$. Maximální zátěžový test začínal na zátěži, která byla stanovena expertním odhadem. Zátěž byla lineárně stupňovaná po $20 \mathrm{~W} \cdot \mathrm{min}^{-1}$ tak, aby trvala minimálně 3,5 minuty a maximálně 6 minut. Všechny druhy testů byly provedeny v časovém intervalu 20 dní s minimálně 2 denní pauzou mezi jednotlivými testy. 
Výsledky

Graf č. 1

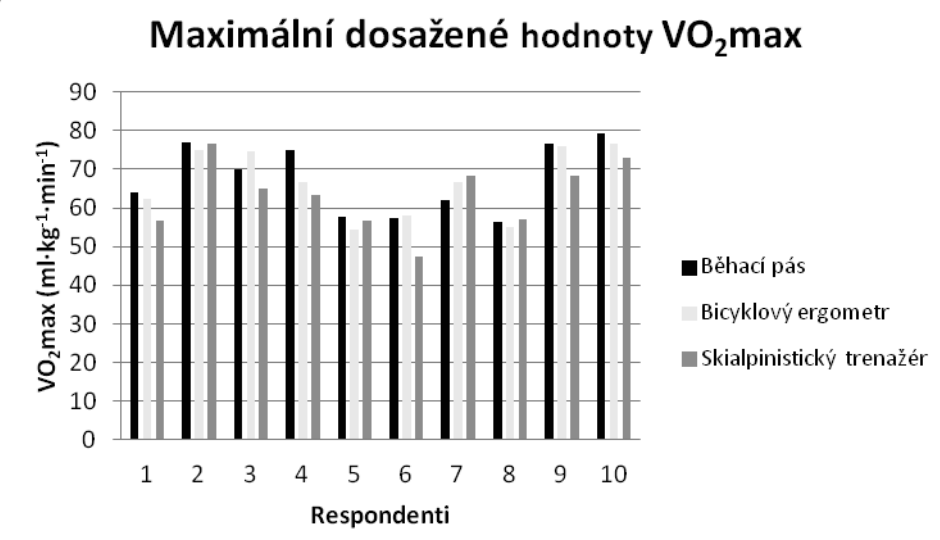

Graf č. 2

Maximální dosažené hodnoty srdeční frekvence

(SF)

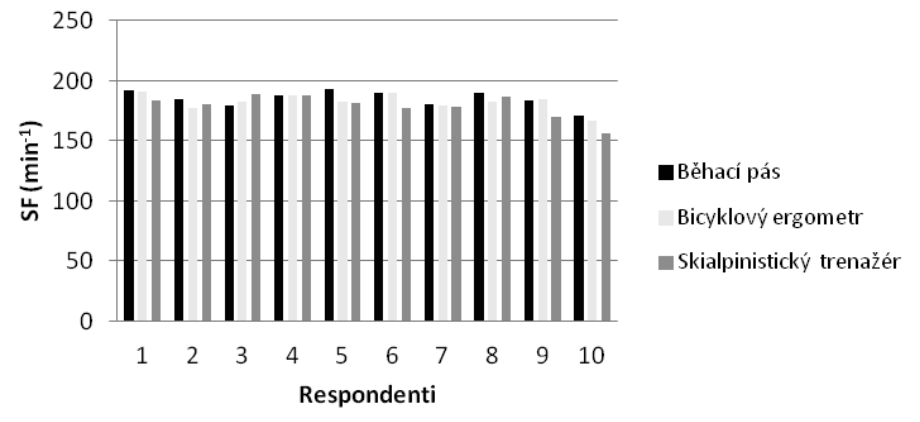

Graf č. 3

Maximální dosažené hodnoty respiračního kvocientu (RER)

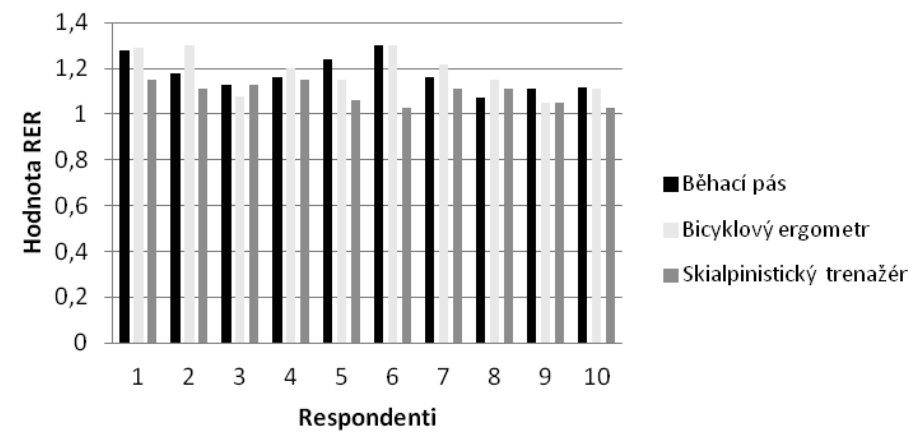


Tabulka č. 1. Maximální dosažené hodnoty

\begin{tabular}{|c|c|c|c|c|c|c|c|c|c|}
\hline \multirow[b]{2}{*}{ Respondenti } & \multicolumn{3}{|c|}{$\mathrm{VO}_{2} \max \left[\mathrm{ml} \cdot \mathrm{kg}^{-1} \cdot \mathrm{min}^{-1}\right]$} & \multicolumn{3}{|c|}{$\mathrm{SF}\left[\mathrm{min}^{-1}\right]$} & \multicolumn{3}{|c|}{ RER } \\
\hline & běhací pás & bic. ergometr & sk. trenažér & běhací pás & bic. ergometr & sk. trenažér & běhací pás & bic. ergomet & sk. trenažér \\
\hline R1 & 64,02 & 62,45 & 56,81 & 192 & 191 & 184 & 1,28 & 1,29 & 1,15 \\
\hline R2 & 77,02 & 74,92 & 76,48 & 185 & 177 & 180 & 1,18 & 1,3 & 1,11 \\
\hline R3 & 70,06 & 74,6 & 65,17 & 179 & 183 & 189 & 1,13 & 1,08 & 1,13 \\
\hline R4 & 74,87 & 66,78 & 63,45 & 188 & 188 & 188 & 1,16 & 1,2 & 1,15 \\
\hline R5 & 57,86 & 54,35 & 56,77 & 193 & 183 & 181 & 1,24 & 1,15 & 1,06 \\
\hline R6 & 57,41 & 58,05 & 47,34 & 190 & 190 & 177 & 1,3 & 1,3 & 1,03 \\
\hline R7 & 61,89 & 66,62 & 68,43 & 180 & 179 & 178 & 1,16 & 1,22 & 1,11 \\
\hline R8 & 56,32 & 54,92 & 57,17 & 190 & 183 & 187 & 1,07 & 1,15 & 1,11 \\
\hline R9 & 76,65 & 75,96 & 68,33 & 184 & 185 & 170 & 1,11 & 1,05 & 1,05 \\
\hline R10 & 79,27 & 76,54 & 73,07 & 171 & 167 & 156 & 1,12 & 1,11 & 1,03 \\
\hline$\mu$ & $67,54+/-2,86$ & $66,521 /-2,78$ & $63,30+/-2,79$ & $185,20+/-2,19$ & $182,60+/-2,23$ & $179,001 /-3,14$ & $1,18+/-0,23$ & $1,19+/-0,29$ & $1,09+/-0,15$ \\
\hline VR & $56,32-79,27$ & $54,35-76,54$ & $47,34-76,48$ & 171-193 & $167-191$ & 156-189 & $1,07-1,3$ & $1,05-1,3$ & $1,03-1,15$ \\
\hline$S$ & 9,05 & 8,8 & 8,83 & 6,91 & 7,06 & 9,94 & 0,76 & 0,92 & 0,47 \\
\hline
\end{tabular}

\section{$\mathrm{R}$ - respondent, $\mu$ - aritmetický průměr, $\mathrm{VR}$ - variační rozpětí, $\mathrm{S}$ - směrodatná odchylka}

Z výsledků jsou patrné individuální reakce organismu na maximální zátěž při různých typech zatížení. V celkovém shrnutí převažují nevyšší hodnoty u pásového ergometru. Nejnižší hodnoty byly nalezeny u skialpinistického trenažéru. U některých respondentů jsou hodnoty ze skialpinistického zátěžového testu na stejné i vyšší úrovni ve srovnání s ostatními testy.

\section{Diskuse}

Rozsah dosažených hodnot naznačuje rozdílnost ve výkonnosti respondentů a jiných faktorů, které měření ovlivňují. Důležitým činitelem při testování na skialpinistickém trenažéru je faktor techniky, který je pro měření významný. Někteří respondenti uvedli, že nebyli schopni dosáhnout maximálního volního úsilí, z důvodu nezvládnutého pohybu v závěrečné části testu. Tato skutečnost se projevuje na základě nedostatečného množství zkušeností s pohybem na kolečkových lyžích. Lyže jsou poměrně vratké a při vysoké frekvenci pohybu kladou velké nároky na udržení stability.

U vysoce trénovaných jedinců, např. běžců, cyklistů, plavců je obvykle možné naměřit maximální př́íjem kyslíku při jejich specifické zátěži, kdy zřejmě hraje úlohu i tréninkem podmíněné optimální zapojení svalstva v souladu s ostatními funkčními systémy (Máček, Radvanský et al., 2011). Toto stanovisko se nám nepodařilo potvrdit pravděpodobně z důvodů specifické lokomoce s lyžemi na pásovém ergometru. Výše uváděný faktor techniky zatím není zcela vyřešen ve prospěch dosažení maximálního volního úsilí.

\section{Závěr}

Nejvyšší průměrné dosažené hodnoty $\mathrm{VO}_{2}$ max byly dosaženy na pásovém ergometru. Respirační kvocient, mimo jiné ukazující míru zatížení organismu, jsme nalezli nejvyšší u bicyklového ergometru. Naměřená data potvrzují vyšší dosažené hodnoty v př́ípadě, kdy je do pohybu zapojeno více svalových skupin. Tato skutečnost neplatí u skialpinistického testu, kde byly nalezeny nejnižší hodnoty RER. To je signálem, že před provedením zátěžového testu je nutná delší zkušenost s touto lokomocí. U skialpinistů, kteří měli předchozí zkušenosti s jízdou na skialpinistickém trenažéru, bylo dosaženo výrazně vyšších hodnot RER než u ostatních respondentů. Současný stav ukazuje, že před provedením maximálního zátěžového testu na skialpinistických kolečkových lyžích je nutný delší trénink. Výsledky prokazují nejmenší odchylky maximálních hodnot u respondentů, kteří měli s jízdou na skialpinistickém trenažéru předchozí zkušenosti. To je sice signálem, že stávající výsledky ze skialpinistického trenažéru nejsou plně využitelné ke srovnávání s ostatními maximálními zátěžovými testy, současně však tato skutečnost podtrhuje význam právě tematického zaměření zde prezentovaného. Pro tuto problematiku je žádoucí nejen vyhledávat dosavadní poznatky, ale současně potřebné poznatky vytvářet, $k$ čemuž je velmi důležité právě provedení vlastních výzkumů a jejich interpretace. 


\section{Literatura}

CANALS, J., HERNÁNDEZ, M., SOULIÉ, J.(2004). Entrenamiento para deportes de Montana, Estonia: Desnivel, 2004, 168 s., 3. vyd. , ISBN 8487746977.

CANCLINI, A. et al.3D (2009). Analysis of technique in elite ski-touring and cross-country skiers engaged in world cup races and on a treadmill,UK: Mayer \& Mayer Sport Ltd., 2009, ISBN 978-1-84126-255-0.

MÁČEK, M., VÁVRA, J. (1988) Fyziologie a patofyziologie tělesné zátěže. Praha: Avicenum, 1988.

MÁČEK, M., RADVANOVSKÝ, J. et al. (2011). Fyziologie a klinické aspekty pohybové aktivity, Praha: Galén, 2011, ISBN 978-80-7262-695-3.

SIDERIS, V. et al. (2010). Spatiotemporal characteristics of a ski mountaineering race during steep uphill, International congress on Science and skiing, Book of abstract, Salzburg : University of Salzburg, 2010, ISBN 978-3-200-02097-9.

TOSI, P. et. al. (2009). Energy cost and efficiency of ski mountaineering. A laboratory study. In book of abstract. Internationl congress Mounatain, Sport \& Health, Rovereto, 2009, s. 68.

TOSI, P., LEONARDI, A., SCHENA, L. (2009). The energy cost of ski mountaineering: efect of speed and ankle loading, Journal of sport medicine and physical fitness, 2009, vol. 49, no 1, s. 25-29.

VILIKUS Z., BRANDEJSKÝ P., NOVOTNÝ V. (2004). Tělovýchovné lékařství, Praha: Karolinum, 2004, ISBN 80-246-0821-9.

VOUTSELAS, V., SOULAS, D, KRITIKOS, A. (2005). Physiological Predictors of Performance in Mountaineering Ski, Inquiries in Sport \& Physical Education, 2005, no 3 (3), s. 277-282. 